\title{
Prevalence of Intestinal Parasites and Associated Risk Factors in Chepang Community of Saktikhor Area, Chitwan, Nepal
}

\author{
Srijana Adhikari, Janak Raj Subedi*, Shanti Chaudhary \\ Central Department of Zoology, Tribhuvan University, Kathmandu, Nepal.
}

\begin{abstract}
Objective: Pathogenic species of protozoa and helminth cause intestinal parasitosis, which continues to be a significant community well-being issue in many regions of the world, especially in pastoral regions of developing countries like Nepal. The study focused on determining the prevalence of intestinal parasitic infections and the associated risk factors among the people of the Chepang community of the Saktikhor area in the Chitwan district.
\end{abstract}

Materials and Methods: A transversal study was conducted between May 2017 and October 2017, with a total of 125 participants. The fecal samples were examined using a wet media (saline media, iodine preparation), concentration and sucrose flotation method. The association between risk factors and parasitic prevalence was evaluated using the Pearson's chi-square test.

Results: The general prevalence of intestinal parasite infection was 52\%. Infections with soil-borne helminth were more common than those with cestodes and protozoa. Common intestinal parasites included Ascaris lumbricoides (69.23\%), Trichuris trichiura (9.23\%), Hookworm (7.69\%), Strongyloides stercoralis (4.62\%), Hymenolepis nana (6.15\%), Taenia sp. (6.15\%), and Entamoeba coli (9.23\%). High prevalence of infection was observed among male $(53.96 \%)$ participants and those aged over 20 years $(69.44 \%)$. Pearson's chi-square test revealed a substantial relationship between prevalence of parasite and age group $(\mathrm{P}=0.0452)$, hand washing material $(\mathrm{P}<0.001)$ and preference for defecation site $(\mathrm{P}<0.001)$.

Conclusion: Hence, a heavy occurrence of intestinal parasites within the Chepang community is particularly evident. There is a need for increased emphasis on intrusion, which can be achieved by improving personal hygiene and sanitation of participants and constructing proper sanitary toilets to prevent the spread of parasitic infections.

Keywords: IPIs, Helminth, Cestode, Protozoan, HMP, NTDs, Community, Prevalence.

\section{INTRODUCTION}

Pathogenic helminth and protozoan species are responsible for intestinal parasitic infections (IPIs) [1]. They belong to neglected tropical diseases (NTDs) [2-5] and are globally endemic [6]. Over $24 \%$ of people worldwide are infected with IPIs, the bulk of who live in underdeveloped nations [7]. These infections are among the widespread disease globally, with sub-Saharan Africa, Southeast Asia, China, South India and South America being the most endemic areas [8,9]. Indeed, a highlight of the human microbiome project was the assessment of intestinal parasites (IPs) [10]. However, given that the project focused predominantly on western populations, the present comprehension of IP distribution unavoidably concentrated on European and American enterotypes [11]. There is less knowledge about the formulation of the IPs in Asian people, notably, in evolving or underdeveloped countries [12]. The IPIs have also affected Nepal, a little, underdeveloped nation in South Asia [13]. Abdominal infection still has an elevated prevalence of $48.9 \%$ [14] and 54.0\% [15] as shown by studies in several regions of Nepal. In Nepal, the most common parasites recorded are Ascaris lumbricoides, Hookworm, Hymenolepis nana, Trichuris trichiura,

*Address correspondence to this author at the Central Department of Zoology, Tribhuvan University, Kathmandu, Nepal.

Email: janzoology@gmail.com
Giardia lambia, Entamoeba histolytica [16]. The parasites play substantial purpose in nutrient biotransformation and inherent immunological reactions [17-19]. The unevenness of the make-up of the parasite has been displayed to be related with the establishment of diseases such as inflammatory intestinal tract infection, corpulence, diarrhea, weakness, and even carcinoma sometimes [20-22].

There are various risk factors associated with the transmission of intestinal parasites. People still have cultural values in rural areas regarding their food and have poor personal hygiene and sanitation [23]. In rural communities, parasites passed down via ingestion are commonly found. In people who regularly eat fresh vegetables and raw meat infected with food borne pests, infection may occur $[24,25]$. In people who walk shoeless on contaminated soil or eat soil-polluted food, soil transmissible parasites (nematodes) may occur [26, 27]. Other elements linked with intestinal parasitosis are the deficiency of drinkable water and warm and moist tropical environment $[28,29]$. One of the Sustainable Development Goals of the United Nations is to end NTDs epidemics by regulating the transmission of IPIs and mitigating potential risk factors (2030 Agenda; Goal 3.3).

Several infectious diseases, like intestinal parasitosis, are 
commonly found in deprived and vulnerable populations like Chepang because of their poor hygiene management, deficiency of clean drinking water, lack of healthcare facility, lack of education, and other basic needs $[15,30,31]$. In addition, they have poor quality of life [32]. A recently conducted experiment on the Chepang community of Makwanpur district revealed an overall prevalence of $39.8 \%$, and the most prevalent helminth and protozoan were $A$. lumbricoides (15.6\%) and E. histolytica (5.4\%) respectively [33]. No other works are recorded in the gut microflora of this community. Understanding how the parasites' alter through communities provides a representative to assess the susceptibility of infection of various communities and to promote the establishment of community-targeted drugs. The objective of this study is to find out the prevalence of intestinal parasites in the Chepang community and to identify the risk factors associated with the prevalence of parasites.

\section{MATERIALS AND METHODS}

\section{Study Design and Area}

A transversal study was conducted between May 2017 to October 2017 and incorporated the Chepang community residing in Saktikhor area of Chitwan district, Nepal (Fig. 1). The Saktikhor area is situated approximately $160 \mathrm{~km}$ west of the Kathmandu valley. For this study, people were randomly selected using voluntary sampling technique. A total of 125 individuals were enlisted. The information on socio-demographic specifics and risk factors were collected using pre-tested question sets. The question sets included the parameters like Gender (Male/Female), Age groups (2-10 years/11-20 years/20 years above), Education (Literate/Illiterate), Occupation (Agriculture/Other), Number of family members $(<5 / \geq 5)$, Feeding habit (Vegetarian/Non-vegetarian), Eating undercooked food (yes/No), Drinking water treatment (Yes/No), Use of handwashing material (Water only/Soap), Defecation site preference (Open field/Toilet) and Barefoot walking habit (Yes/No).

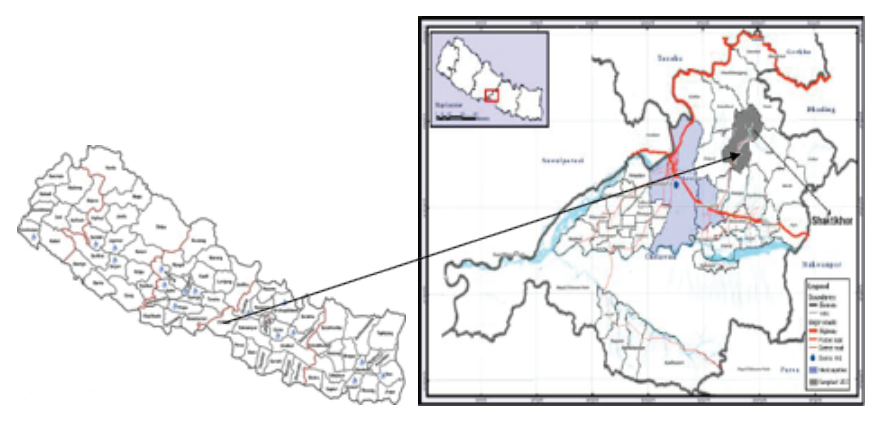

Fig. (1). Map of Nepal Showing Saktikhor Area, Chitwan.

\section{Study Population}

Chepang community is one of the highly marginalized ethnic communities of Nepal, residing on the mountains and sharpest slopes of Chitwan, Dhading, Gorkha, Makawanpur, Lamjung, and Tanahu districts [34]. They have a population of 68,399, accounting for $0.26 \%$ of Nepal's total population [35]. The Chepang people's basic way of living involves hunting, fishing, searching for wild tubers, and conventional method of cultivation in proximity of forests [36].

\section{Sample Collection, Preservation and Examination}

Neat plastic vessels were provided to the participants with thorough guidance about fecal sample collection. The fecal samples were collected in the morning time and preserved in $2.5 \% \mathrm{~K}_{2} \mathrm{Cr}_{2} \mathrm{O}_{7}$ solution before transportation to the laboratory of Central Department of Zoology, Tribhuvan University, Kathmandu. Each sample was examined carefully for the detection of intestinal parasites by Wet mount (saline mounts and iodine preparation), concentration and sucrose floatation method.

\section{Data Analysis}

The data collected from laboratory reports and field surveys were filed as numbers and percent. The R-studio software windows version 1.1.463 was used to analyze the data. Pearson's chi-square test was performed to evaluate the association between potential risk factors and prevalence of intestinal parasite. A p-value of $<0.05$ is considered to be statistically significant.

\section{RESULTS}

\section{Prevalence by Socio-Demographic Characteristics (Age, Sex)}

A total of 125 participants, $63(50.4 \%)$ male individuals and $62(49.6 \%)$ females, were included in this study. The overall prevalence of intestinal parasitic infection was $52 \%(65 / 125)$. The prevalence rate was $53.96 \%(34 / 63)$ in males and $50 \%$ $(31 / 62)$ in females. There was no significant difference in the prevalence of parasites between the two sexes $(p=0.791)$. The participants of the age group 20 above had a higher prevalence rate of $69.44 \%(25 / 36)$ when compared to other age groups [2-10 years $42.85 \%(6 / 14), 11-20$ years $45.85 \%$ (34/75)]. Significant difference was seen in the prevalence of parasites among different age groups $(\mathrm{p}=0.045)$.

\section{Distribution of Parasites}

All together seven species of intestinal parasites were recorded from the fecal sample of the study populations of the Chepang community. Six species were helminths and one was protozoan. The prevalence of intestinal helminths and protozoans was $90.77 \%(59 / 65)$ and $9.23 \%(6 / 65)$, respectively. The most common intestinal parasites were soil-transmitted 
helminths which included Ascaris lumbricoides $69.23 \%$ (45/65), Trichuris trichiura 9.23\% (6/65), Hookworm 7.69\% (5/65), and Strongyloides stercoralis 4.62\% (3/65). Two cestodes and one non-pathogenic protozoan identified were Hymenolepis nana 6.15\% (4/65), Taenia sp. 6.15\% (4/65), and Entamoeba coli $9.23 \%(6 / 65)$ respectively.

\section{Intensity of Single, Double and Triple Infection of Para- sites}

Regarding the intensity of infection, single infection $(84.61 \%$, $55 / 65)$ was more common compared to double $(13.85 \%, 9 / 65)$ and triple infections $(1.54 \%, 1 / 65)$ as shown in Table $\mathbf{1 , 2}$ and 3 respectively. In single infection, the highest intensity was of Ascaris lumbricoides. Similarly, in double infection, the combination of Ascaris lumbricoides and E. coli had highest intensity. The combination of Ascaris lumbricoides, Strongyloides stercoralis and Trichuris trichiura showed triple infection in a participant.

Risk Factors Associated with Intestinal Parasitic Infections

For the analysis of association of risk factors with prevalence of parasite, Pearson's chi-square test was conducted. There was no significant association between intestinal parasitic infection and gender $(\mathrm{p}=0.79)$, education $(\mathrm{p}=0.96)$, occupation ( $p=0.27)$, number of a family members $(\mathrm{p}=0.27)$, feeding habit $(\mathrm{p}=0.15)$, eating undercooked food $(\mathrm{p}=0.50)$, drinking water treatment $(\mathrm{P}=0.05)$, and barefoot walking habit $(\mathrm{p}=0.91)$. However, three risk factors were identified that were associated with parasitic infection. Those were age

Table 1. Intensity of Single Infection of Parasite.

\begin{tabular}{|c|c|c|c|c|c|c|}
\hline S.No. & Parasites & $\begin{array}{c}\text { Total } \\
\text { Infected }\end{array}$ & $\begin{array}{c}\text { No. of } \\
\text { Infected Male }\end{array}$ & $\begin{array}{c}\text { Percentage of } \\
\text { Infected Male (T=65) }\end{array}$ & $\begin{array}{c}\text { No. of } \\
\text { Infected Female }\end{array}$ & $\begin{array}{c}\text { Percentage of } \\
\text { Infected Female (T=65) }\end{array}$ \\
\hline 1. & Ascaris lumbricoides & 39 & 25 & $38.46 \%$ & 14 & $21.54 \%$ \\
\hline 2. & Taenia sp. & 4 & 3 & $4.62 \%$ & 1 & $1.52 \%$ \\
\hline 3. & Hookworm & 3 & 1 & $1.52 \%$ & 2 & $3.08 \%$ \\
\hline 4. & Entamoeba coli & 3 & 1 & $1.52 \%$ & 2 & $3.08 \%$ \\
\hline 5. & Hymenolepis nana & 3 & 2 & $3.08 \%$ & 1 & $1.52 \%$ \\
\hline 6. & Trichuris trichiuria & 3 & 1 & $1.52 \%$ & 2 & $3.08 \%$ \\
\hline & Total & 55 & 33 & $50.77 \%$ & 22 & $33.84 \%$ \\
\hline
\end{tabular}

Table 2. Intensity of Double Infection of Parasites.

\begin{tabular}{|c|c|c|c|c|c|c|}
\hline S.No. & Parasites & No. & $\begin{array}{c}\text { No. of } \\
\text { Infected Male }\end{array}$ & $\begin{array}{c}\text { Percentage of } \\
\text { Infected Male (T=65) }\end{array}$ & $\begin{array}{c}\text { No. of } \\
\text { Infected Female }\end{array}$ & $\begin{array}{c}\text { Percentage of } \\
\text { Infected Female }\end{array}$ \\
\hline 1. & A.lumbricoides + T.trichuria & 1 & - & - & 1 & $1.52 \%$ \\
\hline 2. & A.lumbricoides + H.nana & 1 & - & - & 1 & $1.52 \%$ \\
\hline 3. & Hookworm+E.coli & 1 & - & - & 1 & $1.52 \%$ \\
\hline 4. & E.coli+A.lumbricoides & 3 & 1 & $1.52 \%$ & 2 & $3.08 \%$ \\
\hline 5. & T.trichuris+S.stercoralis & 1 & - & - & 1 & $1.52 \%$ \\
\hline 6. & Hookworm +E.coli & 1 & - & - & 1 & $1.52 \%$ \\
\hline 7. & S.stercoralis+E.coli & 1 & - & - & 1 & $1.52 \%$ \\
\hline & Total & 9 & 1 & $1.52 \%$ & 8 & $12.31 \%$ \\
\hline
\end{tabular}

Table 3. Intensity of Triple Infection of Parasites.

\begin{tabular}{|c|c|c|c|c|c|c|}
\hline S.No. & Parasites & No & $\begin{array}{c}\text { No. of } \\
\text { Infected Male }\end{array}$ & $\begin{array}{c}\text { Percentage of } \\
\text { Infected Male (T=65) }\end{array}$ & $\begin{array}{c}\text { No. of } \\
\text { Infected Female }\end{array}$ & $\begin{array}{c}\text { Percentage of } \\
\text { Infected Female }\end{array}$ \\
\hline 1. & $\begin{array}{c}\text { T. trichuria }+ \text { S. stercoralis } \\
+ \text { A. lumbricoides }\end{array}$ & 1 & - & - & 1 & $1.52 \%$ \\
\hline & Total & 1 & - & - & 1 & $1.52 \%$ \\
\hline
\end{tabular}


groups $(p=0.045)$, hand washing material $(p<0.001)$ and defecation site preference $(\mathrm{p}<0.001)$.

\section{DISCUSSION}

The general prevalence of intestinal parasite in Chepang community living in the Saktikhor area of Chitwan district was $52 \%$. A recent study of the same ethnic community of Makwanpur district [33] and studies on other indigenous communities of Nepal $[12,37]$ showed lower prevalence rates than the present study. Moreover, the prevalence rate was also lower in both national and international scenarios too done withschool age children of different parts of the world [38-43]. The outcome of this study documented the high prevalence of soil-transmitted helminth compared to cestode and protozoan parasite. The result is similar to the researches done in intestinal parasite of the children, which also showed a high prevalence of helminth parasites in those children [44-46]. However, the study contradicted the findings of some previous studies which discovered a low prevalence of helminth parasites $[1,47]$. The finding of this study is similar to some other works as they also reported a low prevalence of protozoan parasite $[23,48]$. The variation of intestinal parasites in these communities may be due to variation in territory, age groups, education, environmental sanitation, and cleanliness behavior of the members.

Gender-wise, the prevalence rate was slightly higher in males compared to females. This result is in accordance with a retrospective study in a tertiary care hospital of Nepal [49] and in studies of parasites in children of Nepal [50-53] and other countries $[54,55]$. Additionally, the age-wise prevalence was higher in the age group of above 20 years which is slightly similar to the study in human intestinal parasite of Shiagu of Abia state [56]. The high prevalence of parasites in males and in the age group above 20 years might be because they are the bread earners of the family and mostly work outside of the house in fields without using any safety measures to prevent parasite infection.

Ascaris lumbricoides was the most prevalent helminth recorded with a prevalence rate of $69.23 \%$. The result is similar to the findings of various studies [56-59] which also recorded a high prevalence of $A$. lumbricoides. The other recorded helminths in this study were T. trichiura, Hookworm, and Strongyloides stercoralis. This high prevalence of helminths, particularly, A. lumbricoidesin the study population might be due to poor hygiene conditions, lack of awareness, open place defecation, and contamination of food and water. A. lumbricoides eggs can survive a long time in the environment compared to other helminth eggs [37]. This might be the reason that its prevalence rate is higher than other helminths. The occurrence of cestodes like Taenia sp. and Hymenolepis nana in the study population may be due to consumption of uncooked or inadequately cooked meat. The only protozoan parasite recorded in this study is Entamoeba coli which contributes $9.23 \%$ of total infection. The finding of this research is in agreement with the study in school children of Kathmandu [60] and South Chennai, India [61] which also recorded the prevalence of $E$. coli as protozoan parasite in their study. Entamoeba coli are generally non-pathogenic. However, it sometimes causes diarrhea and its occurrence may be because of fecal contamination of water source. Various studies on the intensity of parasitic infections showed a high prevalence of single parasitic infection than that of double and multiple infections [39, 62, 63]. These studies resemble our finding, which also showed the high intensity of a single infection, and the least was a triple infection. This study also assessed the relationship between prevalence of parasite and potential risk factors among the participants.

The prevalence of parasite was irrelevant with gender, education, occupation, number of family members, feeding habit, eating undercooked food, drinking water treatment, and barefoot walking habit of the participants. The finding of our study was consistent with earlier studies conducted in different parts of Thailand [47, 64-66]. Pearson's chi-square test revealed a notable relationship amid the prevalence of intestinal parasite and age groups. The participants of the age group above 20 years had a significantly larger infection rate compared to other age groups. Also, the rate of infection was remarkably linked with handwashing material and defecation site preference. People who used to wash their hands only with water and those who defecate in open places were mostly infected. The results are similar to the findings obtained in other previous works too [67-69]. As a whole, a remarkable relationship was seen between the prevalence of parasites and age group, use of handwashing material, and defecation site preference of the participants of that specific examined region.

\section{CONCLUSION}

Hence, this study shows a significant occurrence of intestinal parasites among the Chepang people of the Saktikhor area of Chitwan district. These infections result mainly from poor hygiene and sanitation condition of the people of that area and lack of proper sanitary toilets. Consequently, the concentration on intrusion should be given to curtail infection rate in that particular area which can be done by improving personal hygiene and sanitation of the participants and by constructing proper sanitary toilets. This, in turn, will help to prevent contamination of soil, food, and water.

\section{AUTHORS' CONTRIBUTION}

Srijana Adhikari : Data curation, formal analysis, investigation and writing-original draft.

Janak Raj Subedi : Conceptualization, data curation, investigation, methodology, supervision, writing-review \& editing. 
Shanti Chaudhary : Conceptualization, methodology, writing-review \& editing.

\section{CONFLICT OF INTEREST}

Declared none.

\section{ACKNOWLEDGEMENTS}

We are grateful to all the study participants and their families for their cooperation in this study. The authors are thankful to Ms. Maria Baig, Editorial Manager Publication (HOD), National Journal of Health Sciences (NJHS) for regular communication and handling the manuscript. We would like to thank the staff of the Central Department of Zoology, Faculty of Science and Technology, Tribhuvan University, Kathmandu.

\section{REFERENCES}

[1] Suntaravitun P, Dokmaikaw A. Prevalence of intestinal protozoan infections among schoolchildren in Bang Khla District, Chachoengsao Province, central Thailand. Asian Pac J Trop Dis 2017; 7: 523-6. DOI: 10.12980/apjtd.7.2017D7-142

[2] WHO. Working to overcome the global impact of neglected tropical diseases: First WHO report on neglected tropical diseases. Geneva: World Health Organization 2010.

[3] Collier P. The bottom billion: why the poorest countries are failing and what can be done about it. Oxford: Oxford University Press 2007.

[4] Hotez PJ, Fenwick A, Savioli L, Molyneux DH. Rescuing the bottom billion through control of neglected tropical diseases. Lancet 2009; 373: 1570-5. DOI: 10.1016/S0140-6736(09)60233-6

[5] Savioli L, Smith H, Thompson A. Giardia and Cryptosporidium the neglected diseases initiative. Trends Parasitol 2006; 22(5): 203-8. DOI: 10.1016/j.pt.2006.02.015

[6] Sitotaw B, Mekuriaw H, Damtie D. Prevalence of intestinal parasitic infections and associated risk factors among Jawi primary school children, Jawi town, north-west Ethiopia. BMC Infect Dis 2019; 19(1): 341. DOI: 10.1186/s12879-019-3971-x

[7] WHO. Soil-transmitted helminth infections: Fact sheet no. 366. Geneva: World Health Organization 2015.

[8] Ahmed A, Al-Mekhlafi HM, Surin J. Epidemiology of soil-transmitted helminthiases in Malaysia. Southeast Asian J Trop Med Public Health 2011; 42: 527-38.

[9] Ng JV, Belizario VY, Claveria FG. Determination of soil-transmitted helminth infection and its association with hemoglobin levels among Aeta schoolchildren of Katutubo Village in Planas, Porac, Pampanga. Phil Sci Lett 2014; 7 : 73-80.
[10] Turnbaugh PJ, Ley RE, Hamady M, Fraser-Liggett CM, Knight R, Gordon JI. The human microbiome project. Nature 2007; 449: 804-810. DOI: 10.1038/nature06244

[11] Gordon JI. Honor thy gut symbionts redux. Science 2012; 336: 1251-3. DOI: $10.1126 /$ science. 1224686

[12] Chong CW, Ahmad AF, Lim YA, et al. Effect of ethnicity and socioeconomic variation to the gut microbiota composition among pre-adolescent in Malaysia. Scientific Rep 2015; 5: 13338. DOI: $10.1038 /$ srep 13338

[13] Chandrashekhar T, Joshi H, Gurung M, et.al. Prevalence and distribution of intestinal parasitic infection among school children in Kaski district, Western Nepal. J Med Biomed Res 2009; 4: 78-82. DOI: 10.4314/jmbr.v4i1.10672

[14] Gyawali P. Parasitic diseases of indigenous community (Kumal) in Nepal. Nepal J Sci Technol 2013; 13: 175-8. DOI: 10.3126/njst.v13i2.7731

[15] Gyawali P, Khanal S, Soares MRJ. Helminth infections in an Indigenous Community. Glob J Med Res 2013; 13(3): 33-9.

[16] Yadav K, Prakash S. Study of intestinal parasitosis among school children of Kathmandu Valley. Nepal Asian J Biomed Pharm Sci 2016; 6: 40-7.

[17] Dave M, Higgins PD, Middha S, Rioux KP. The human gut microbiome: Current knowledge, challenges, and future directions. Transl Res 2012; 160: 246-57. DOI: 10.1016/j.trsl.2012.05.003

[18] Maslowski KM, Mackay CR. Diet, gut microbiota and immune responses. Nat Immunol 2011; 12: 5-9. DOI: 10.1038/ni0111-5

[19] Nicholson JK, Holmes E, Kinross J, et al. Host-gut microbiota metabolic interactions. Science 2012; 336: 1262-7. DOI: 10.1126/science. 1223813

[20] Yan F, Polk DB. Commensal bacteria in the gut: Learning who our friends are. Curr Opin Gastroenterol 2004; 20: 565-71. DOI: $10.1097 / 00001574-200411000-00011$

[21] Lepage P, Hasler R, Spehlmann ME, et al. Twin study indicates loss of interaction between microbiota and mucosa of patients with ulcerative colitis. Gastroenterology 2011; 141: 227-36. DOI: 10.1053/j.gastro.2011.04.011

[22] Ley RE, Turnbaugh PJ, Klein S, Gordon JI. Microbial ecology: Human gut microbes associated with obesity. Nature 2006; 444: 1022-3. DOI: 10.1038/4441022a

[23] Boonjaraspinyo S, Boonmars T, Kaewsamut B, et al. A cross-sectional study on intestinal parasitic infections in rural communities, northeast Thailand. Korean J Parasitol 2013; 51(6): 727-34. DOI: 10.3347/kjp.2013.51.6.727

[24] Dorny P, Praet N, Deckers N, Gabriel S. Emerging food-borne parasites. Vet Parasitol 2009; 163: 196-206. DOI: 10.1016/j.vetpar.2009.05.026 
[25] Macpherson CN, Gottstein B, Geerts S. Parasitic food-borne and water-borne zoonoses. Rev Sci Tech 2000; 19: 240-58. DOI: $10.20506 /$ rst.19.1.1218

[26] Naish S, McCarthy J, Williams GM. Prevalence, intensity and risk factors for soil-transmitted helminth infection in a South Indian fishing village. Acta Trop 2004; 91: 177-87. DOI: 10.1016/j.actatropica.2004.04.004

[27] Nyarango RM, Aloo PA, Kabiru EW, Nyanchongi BO. The risk of pathogenic intestinal parasite infections in Kisii Municipality, Kenya. BMC Public Health 2008; 8: 237. DOI: 10.1186/1471-2458-8-237

[28] Hernandez AD, Poole A, Cattadori IM. Climate changes influence free-living stages of soil-transmitted parasites of European rabbits. Glob Chang Biol 2013; 19: 1028-42. DOI: $10.1111 / \mathrm{gcb} .12106$

[29] Marcogliese DJ, Cone DK. Parasite communities as indicators of ecosystem stress. Parassitologia1997; 39: 227-32.

[30] Subba C, Pyakuryal B, Bastola TS, Subba MK, Raut NK, Karki B. A Study on the socio-economic status of indigenous peoples in Nepal. Ghattekulo-Anamnagar, Kathmandu, Nepal: Lawyers' Association for Human Rights of Nepalese Indigenous peoples 2014

[31] Pokharel T. Poverty in Nepal: Characteristics and challenges. Invest Dev 2015; 11: 44-56.

[32] United Nations Resident and Humanitarian Coordinator's Office. Field bulletin nr. 47: Chepangs' struggle for survival: Views from Makwanpur and Chitwan districts. 2012; Available at: https://reliefweb.int/sites/reliefweb.int/files/resources/Full\%20Report_1021.pdf

[33] Khadka S, Sapkota S, Adhikari, S. et al. Intestinal parasitoses among Chepang and Musahar Community people of Makwanpur and Nawalparasi districts of Nepal. Acta Parasit 2021; 66(1): 146-54. DOI: $10.1007 / \mathrm{s} 11686-020-00269-0$

[34] Sharma G, Aryal B. Household economics of chepang people in chitwan. Econ Literature 2016; 13: 39-45. DOI: 10.3126/el.v13i0.19149

[35] Population monograph of Nepal Volume II (social demography). Ramshah Path Kathmandu: Central Bureau of Statistics 2012; Available at: https://nepalindata.com/resource/population-monograph-of-nepal-volume-ii-social-demography/

[36] Gurung GM. Report from a Chepang Village: Society, Culture and Environment. Kathmandu, Nepal, 1995.

[37] Chaudhary S, Subedi JR. Comparative prevalence of intestinal helminths in Satar and Chaudhary communities of Birtamode municipality, Jhapa, Nepal. Nat J Health Sci 2020; 5: 4-12. DOI: $10.21089 /$ njhs.51.0004

[38] Mordi RM, Ngwodo POA. A study of blood and gastro-intesti- nal parasites in Edo state. Afr J Biotech 2007; 6: 2201-7.DOI: 10.5897/AJB2006.000-5438

[39] Shrestha R, Maharjan M. Prevalence of intestinal helminth parasites among school children of Bhaktapur District, Nepal. Nepal J Zool 2013; 1: 48-59.

[40] Opara FN, Udoye AA, Okere PU, Osula FOU, IwualaMOE. The prevalence of intestinal helminth infections in primary school children in Owerii Municipality, Imo state, Nigeria. J Parasit Dis 2007; 31(1): 44-8.

[41] Uga S, Rai SK, Kimura K, Rai G, Kimura D, Wakasgi M. Parasites detected from diarrheal stool samples collected in Nepal. Southeast Asian J Trop Med Public Health 2004; 35(1): 19-23.

[42] Bhandari N, Kausaph V, Neupane GP. Intestinal parasitic infection among school age children. J Nepal Health Res Council 2011; 9(18): 30-2.

[43] Sah RB, Baral R, Shah U, Jha N. A Study of Prevalence of helminthic infections and associated risk factors among the school children of Biratnagar Sub-metropolitan, Eastern region of Nepal. Int J Curr Res Med Sci 2016; 2(4): 8-15.

[44] Malla B, Sherchand JB, Ghimire P, BC RK, Gauchan P. Prevalence of intestinal parasitic infection and malnutrition among children in rural community Sarlahi, Nepal. J Nepal Health Res Council 2004; 2(1): 1-4.

[45] Chongbang R, Dangol P, Chakraworti A, Khanal H. Parasitic infection among children of Squatter community in Dharan 9 municipality, sunsari, Nepal. Int J Appl Sci Biotechnol 2016; 4(2): 203-6. DOI: 10.3126/ijasbt.v4i2.15099

[46] Golia S, Sangeetha KT, Vasudha CL. Prevalence of parasitic infections among primary school children in Banglore. Int $\mathrm{J}$ Basic Appl Med Sci 2014; 4(1): 356-61.

[47] Boontanom P, Mungthin M, Tan-Ariya P, Naaglor T, Leelayoova S. Epidemiology of giardiasis and genotypic characterization of Giardia duodenalis in preschool children of a rural community, central Thailand. Trop Biomed 2011; 28: $32-39$

[48] Songserm N, Promthet S, Wiangnon S, Sithithaworn P. Prevalence and co-infection of intestinal parasites among Thai rural residents at high-risk of developing cholangiocarcinoma: A crosssectional study in a prospective cohort study. Asian Pac J Cancer Prev 2012; 13: 6175-9. DOI: 10.7314/APJCP.2012.13.12.6175

[49] Singh GK, Parajuli KP, Shrestha M, Pandey S, Yadav SC. The prevalence of intestinal parasitic infestation in a Tertiary Care Hospital- A Retrospective Study. J Nobel Med Coll 2014; 2(1): 13-5. DOI: 10.3126/jonmc.v2i1.7666

[50] Tandulkar S, Sherchand JB, Thapa $\mathrm{P}$, et al. Intestinal parasite infection among school going children in Kathmandu valley. Austin J Pediatr 2015; 2: 1-4. 
[51] Khanal LK, Chaudhary DR, Rai SK, et al. Prevalence of intestinal worm infestation among school children in Kathmandu, Nepal. Nepal Med Coll J 2011; 13(4): 272-4.

[52] Pradhan P, Bhandary S, Shakya PR, Acharya T, Shrestha A. Prevalence of intestinal parasitic infections among public school children in a rural Village of Kathmandu valley. Nepal Med Coll J 2014; 16(1): 50-3.

[53] Pandey S, Lama A, Shrestha RB. Intestinal parasitic infections among school children of northern Kathmandu, Nepal. Asian Pacific J Trop Dis 2015; 5(1): 89-92. DOI: $10.1016 /$ S2222-1808(15)60864-7

[54] Mohammed J, Hussein AA. Frequency of intestinal parasitic infection among children under 5 years of age in Baghdad Province. Int J Adv Res 2014; 2(8): 332-7.

[55] Wordmann M, Polman K, Heredia LTM, et al. Prevalence and risk factors of intestinal parasites in Cuban Children. Trop Med Int Health 2006; 2(12): 1813-20. DOI: $10.1111 /$ j.1365-3156.2006.01745.x

[56] NdukaFO, Nwaugo VO, Nwachakwu NC.Human intestinal parasite infection in Shiagu, a lead mining area of Abia state. Anim Res Int 2006; 3(3): 505-7. DOI: 10.4314/ari.v3i3.40779

[57] Nishiura M. Study on living circumstances of children suffering from diarrhoel disease. J Nepal 2002; 19: 11-21.

[58] Oli KB. Prevalence of intestinal parasites in Tharu community of Pawannagar VDCs of Dang district in relation to their socio economic status. Thesis. Kirtipur, Kathmandu, Nepal: Central Department of Zoology, Tribhuvan University 2016.

[59] Ojurongbe O, Oyesji KF, Oja JA, et al. Soil transmitted helminth infections among primary school children in Lle-lfe Southwest, Nigeria: A cross-sectional study. Int Res J Med Med Sci 2014; 2(1): 6-10.

[60] Thapa D, Rai SK, Lekhak B, Rai RR. Study of parasitic infection among children of Sukumbasi Basti in Kathmandu Valley. Nepal Med Coll 2011; 13(1): 7-10.

[61] Dhanabal J, Selvadoss PP. Muthuswamy Comparative study of prevalence of intestinal parasites in low socioeconomic areas from south Chennai. J Parasitol Res 2014; Article ID 630968: 1-7. DOI: $10.1155 / 2014 / 630968$

[62] Mordi RM, Ngwodo POA. A study of blood and gastro-intestinal parasites in Edo state. Afr J Biotech 2007; 6: 2201-7. DOI: 10.5897/AJB2006.000-5438

[63] Opara FN, Udoye AA, Okere PU, Osula FOU, Iwuala MOE. The prevalence of intestinal helminth infections in primary school children in Owerii Municipality, Imo state, Nigeria. J Parasit Dis 2007; 31(1): 44-8.

[64] Punsawad C, Phasuk N, Bunratsami S, Thongtup K, Siripakonuaong N, Nongnaul S. Prevalence of intestinal parasitic infection and associated risk factors among village health volunteers in rural communities of southern Thailand. BMC Public Health 2017; 17: 564. DOI: $10.1186 / \mathrm{s} 12889-017-4486-2$

[65] Jiraanankul V, AphijirawatW, Mungthin M, et al. Incidence and risk factors of hookworm infection in a rural community of central Thailand. Am J Trop Med Hyg 2011; 84: 594-8. DOI: 10.4269 /ajtmh.2011.10-0189

[66] Ruankham W, Bunchu N, Koychusakun P. Prevalence of helminthic infections and risk factors in villagers of Nanglae Sub-District, Chiang Rai province, Thailand. J Med Assoc Thai 2014; 97 (4): 29-35.

[67] Elyana FN, AL-Mekhlafi HM, Jthoi I, et al. A tale of two communities: Intestinal parasitism among Orang Asli and Malay communities in rural Terengganu, Malaysia. Parasite Vectors 2016; 9(1): 398. DOI: 10.1186/s13071-016-1678-Z

[68] Ziegelbauer K, Speich B, Mausezahl D, Bos R, Keiser J, Utzinger J. Effect of sanitation on soil transmitted helminth infection: Systematic review and meta-analysis. PloS Med 2012; 9(1): 5. DOI: 10.1371/journal.pmed.1001162

[69] Schmidlin T, Hurlimann E, Silue KD, et al. Effect of hygiene and defecation behavior on helminths and intestinal protozoa infection in Taabo, Cote D'Ivore. PloS One 2013; 8(6): e65722. DOI: 10.1371/journal.pone.0065722 